Notre Dame Law Review

Volume 85 | Issue 3

Article 1

$3-1-2010$

\title{
Plausibility Pleading Revisited and Revised: A Comment on Ashcroft v. Iqbal
}

Robert G. Bone

Follow this and additional works at: http://scholarship.law.nd.edu/ndlr

\section{Recommended Citation}

Robert G. Bone, Plausibility Pleading Revisited and Revised: A Comment on Ashcroft v. Iqbal, 85 Notre Dame L. Rev. 849 (2010). Available at: http://scholarship.law.nd.edu/ndlr/vol85/iss3/1

This Article is brought to you for free and open access by NDLScholarship. It has been accepted for inclusion in Notre Dame Law Review by an authorized administrator of NDLScholarship. For more information, please contact lawdr@nd.edu. 


\title{
ARTICLES
}

\section{PLAUSIBILITY PLEADING REVISITED \\ AND REVISED: \\ A COMMENT ON ASHCROFT V. IQBAL}

\author{
Robert G. Bone*
}

This Article critically examines the Supreme Court's most recent decision on Rule $8(a)(2)$ pleading standards, Ashcroft v. Iqbal, decided in May 2009. The Article supplements and extends the analysis in my recent article, Twombly, Pleading Rules, and the Regulation of Court Access, which examined the Supreme Court's seminal Bell Atlantic Corp. v. Twombly decision and evaluated the costs and benefits of screening meritless suits at the pleading stage. In this Article, I argue that Iqbal does much more than clarify and reinforce key points in Twombly; it takes Twombly's plausibility standard in a new and ultimately ill-advised direction. My criticism has two parts. First, Iqbal adopts a "two-pronged approach" that filters legal conclusions in the first prong before applying the plausibility standard to factual allegations in the second. I argue that this two-pronged approach is incoherent. There is only one prong: the judge must determine whether the complaint, interpreted as a coherent whole, plausibly supports each element of the legal claim. The second problem with Iqbal runs deeper. Iqbal screens lawsuits more aggressively than Twombly, and does so without adequate consideration of the policy stakes. In particular, Iqbal applies a thick screening model that aims to screen weak as well as meritless suits, whereas Twombly applies a thin screening

(c) 2010 Robert G. Bone. Individuals and nonprofit institutions may reproduce and distribute copies of this Article in any format, at or below cost, for educational purposes, so long as each copy identifies the author, provides a citation to the Notre Dame Law Review, and includes this provision and copyright notice.

* G. Rollie White Professor, The University of Texas School of Law. I would like to thank my BU colleague Ward Farnsworth and my UT colleague Patrick Woolley for their helpful comments, as well as Christy Renworth and Bob Little for their excellent research assistance. I presented much of this Article to the January 7, 2010 meeting of the Standing Committee on Rules of Practice and Procedure, and I would like to thank the members of the Committee for a useful discussion of the ideas. 
model that aims to screen only truly meritless suits. The thick screening model is highly problematic on policy grounds, even in cases like Iqbal that involve qualified immunity. Moreover, the Supreme Court is not institutionally well equipped to decide whether strict pleading is desirable, especially when it implements a thick screening model. Those decisions should be made through the formal Rules Enabling Act process or by Congress.

\section{INTRODUCTION}

Court access has become a matter of intense concern today in the wake of two major pleading decisions of the United States Supreme Court. The first, Bell Atlantic Corp. v. Twombly, ${ }^{1}$ held that a plaintiff must allege sufficient facts to state a "plausible" claim for relief." Twombly's critics-and there are many-complain that the plausibility standard unfairly impedes court access for meritorious suits. ${ }^{3}$ The second decision, Ashcroft v. Iqbal, ${ }^{4}$ issued on May 18, 2009, applies the plausibility standard to allegations that are less obviously deficient than those in Twombly and, in so doing, signals an even stricter approach to pleading requirements. Provoked by the Iqbal decision, many critics now believe that it is imperative to undo the effects of plausibility pleading. On July 22, 2009, Senator Arlen Specter introduced the Notice Pleading Restoration $\mathrm{Act}^{5}$ aimed at reinstating the liberal notice pleading standards existing prior to Twombly, and on November 19, 2009, Representative Jerrold Nadler introduced the Open Access to Courts Act ${ }^{6}$ for the same purpose.

1550 U.S. 544 (2007).

2 See id. at 556, 570.

3 See, e.g., Lonny S. Hoffman, Burn Up the Chaff with Unquenchable Fire: What Two Doctrinal Intersections Can Teach Us About Judicial Power Over Pleadings, 88 B.U. L. Rev. 1217, 1260-64 (2008); A. Benjamin Spencer, Plausibility Pleading, 49 B.C. L. REv. 431, 433, 479-83 (2008).

4129 S. Ct. 1937 (2009).

5 S. 1504, 111th Cong. (2009). The Notice Pleading Restoration Act provides in full:

Except as otherwise expressly provided by an Act of Congress or by an amendment to the Federal Rules of Civil Procedure which takes effect after the date of enactment of this Act, a Federal court shall not dismiss a complaint under rule 12(b) (6) or (e) of the Federal Rules of Civil Procedure, except under the standards set forth by the Supreme Court of the United States in Conley v. Gibson, 355 U.S. 41 (1957). Id. $\S 2$.

6 H.R. 4115, 111 th Cong. (2009). The Open Access to Courts Act provides in relevant part:

A court shall not dismiss a complaint under subdivision (b) (6), (c), or (e) of Rule 12 of the Federal Rules of Civil Procedure unless it appears beyond 
I discussed Twombly, plausibility pleading, and court access in a previous article. ${ }^{7}$ This Article extends that earlier work by examining what Iqbal adds to Twombly. Although the Court purports to be applying Twombly's plausibility standard, a fair reading of the majority opinion shows that Iqbal's version of plausibility is significantly stricter than Twombly's. Moreover, the Iqbal Court enlists plausibility for a broader purpose. Twombly uses plausibility to screen only for truly meritless suits, but Iqbal uses it to screen for weak lawsuits too. The difference is crucial. Screening weak lawsuits raises much more complex and controversial policy questions than screening meritless suits, and the Supreme Court is not well equipped institutionally to address those policy questions. They are better left to the committees involved in the formal rulemaking process or to Congress.

Moreover, although a response to Iqbal is needed, neither of the proposed bills is the right response. It is not at all clear that the best approach is to restore pre-Twombly law. There is much to commend Twombly's thin plausibility standard and those benefits should be considered seriously in designing an optimal pleading approach. ${ }^{8}$ A clear understanding of the differences between Iqbal and Twombly makes it possible to consider Twombly's virtues without the taint of Iqbal's vices.

The body of this Article is divided into four parts. Part I describes the Twombly and Iqbal decisions. Part II focuses on what Iqbal adds doctrinally to Twombly. Iqbal's most important doctrinal contribution is to frame the analysis formally as a "two-pronged approach." ${ }^{2}$ The judge must first exclude "legal conclusions" before applying the plausibility standard to the "factual allegations" that remain. ${ }^{10}$ Although Twombly also excluded legal conclusions, it did so in a very different way than Iqbal.

Part III sets the stage for the critical discussion in Part IV by briefly recounting the history of the law-fact distinction in pleading.

doubt that the plaintiff can prove no set of facts in support of the claim which would entitle the plaintiff to relief. A court shall not dismiss a complaint under one of those subdivisions on the basis of a determination by the judge that the factual contents of the complaint do not show the plaintiff's claim to be plausible or are insufficient to warrant a reasonable inference that the defendant is liable for the misconduct alleged.

Id. $\S 2(\mathrm{a})$.

7 Robert G. Bone, Twombly, Pleading Rules, and the Regulation of Court Access, 94 IOWA L. Rev. 873 (2009).

8 Moreover, even a somewhat stricter standard might be justified on cost-benefit grounds for some types of cases, at least as long it is combined with access to limited before dismissal discovery. See discussion infra Parts IV.C-D.

9 Iqbal, 129 S. Ct. at 1950.

10 Id. 
Part IV then makes two criticisms of Iqbal. First, it argues that the twopronged approach is incoherent. The first prong makes no sense because there is no clear division between legal conclusions and factual allegations. Classifying allegations as legal conclusions is no different than saying that those allegations are too general to support a plausible case, and that determination must be made by applying the plausibility standard to the complaint interpreted as a whole.

The second criticism strikes deeper. Iqbal's two-pronged approach obscures the fact that its pleading standard is stricter than Twombly's. By eliminating the key allegations in the complaint as "legal conclusions" in the first prong, the Court makes the second prong's plausibility analysis seem like a straightforward and relatively easy application of Twombly. But it is not. Adding the key allegations back into the complaint shows just how much more demanding Iqbal is than Twombly.

In particular, Iqbal applies a thick screening model that aims to screen weak as well as meritless suits, whereas Twombly applies a thin screening model that aims to screen only truly meritless suits. The thick screening model is highly problematic on policy grounds, even in cases like Iqbal that involve qualified immunity. Moreover, the Supreme Court is not institutionally well-equipped to decide whether strict pleading is desirable on a case-specific basis, especially when the strict pleading standard implements a thick screening model. Those decisions should be made through the Enabling Act's formal rulemaking process or, as a second best alternative, by Congress.

\section{A BRIEF SummaRY OF TWOMBLY AND IQBAL}

\section{A. Bell Atlantic Corp. v. Twombly}

Bell Atlantic Corp. v. Twombly was a nationwide antitrust class action brought under Section 1 of the Sherman Act against the four largest telecommunications companies in the United States. The plaintiffs claimed that the defendants had conspired to divide territory and deter new entry by agreeing not to enter one another's markets and to resist entry by others. ${ }^{11}$

The Supreme Court held that the complaint failed to state a claim upon which relief could be granted and reinstated the district court's 12(b)(6) dismissal. ${ }^{12}$ The seven-Justice majority concluded that the allegations of parallel conduct-that no defendant ever attempted to enter another's market and that they all used similar

11 See Bell Atl. Corp. v. Twombly, 550 U.S. 544, 550-51 (2007).

12 Id. at 566, 570. 
entry-deterrence strategies-were insufficient because the conduct alleged was exactly what one would expect from vigorous competition in the telecommunications market, given its distinctive history and structure. ${ }^{13}$ As for the few allegations that directly stated the existence of an agreement, the Court treated them as "merely legal conclusions resting on the prior allegations" 14 and therefore insufficient to make the existence of an agreement plausible.

In my previous article, I argued that Twombly changed pleading law on both a policy and a doctrinal level. ${ }^{15}$ On the policy level, the Court recognized the importance of using pleading to screen meritless suits. Before Twombly, the standard approach, notice pleading, envisioned the sole function of a complaint as giving fair notice to the defendant of what the dispute was generally about. ${ }^{16}$ The Twombly complaint clearly satisfied this standard; the defendants knew what the plaintiffs were complaining about and could easily admit or deny the allegations. The Court held, however, that pleading standards should do more than give notice; they should also screen for meritless suits. ${ }^{17}$

On the doctrinal level, the Court rejected the most generous version of notice pleading, the so-called "possibility" standard, that tolerates allegations if they are merely consistent with the possibility of wrongdoing. The Court held that Federal Rule of Civil Procedure 8(a) (2)'s "short and plain statement" standard requires plausibility, not just possibility. ${ }^{18}$ The plaintiff must allege sufficient facts to support a plausible inference of the existence of each element of the legal claim. And the plaintiffs in Twombly failed to do this for the conspiracy element of their Sherman Act claim. ${ }^{19}$

\section{B. Ashcroft v. Iqbal}

Ashcroft v. Iqbal was a suit for damages brought by two Arab Muslim men against federal officials based on violations of the U.S. Consti-

13 In addition to the parallel conduct, the plaintiffs also relied on a statement by the CEO of Qwest Communications. Id. at 551. The Court concluded that when read in context, this statement did not have the meaning the plaintiffs attributed to it. Id. at 568 n.13.

$14 \quad I d$. at 564.

15 See Bone, supra note 7, at 882-90.

16 See Conley v. Gibson, 355 U.S. 41, 47-48 (1957), abrogated by Twombly, 550 U.S. 544; 5 Charles Alan Wright \& Arthur R. Miller, Federal Practice and Procedure $\S 1216$ (3d ed. 2004 \& Supp. 2009).

17 See Twombly, 550 U.S. at 558.

18 Id. at 555-56.

19 Id. at 566. 
tution and federal statutes. ${ }^{20}$ The claims focused on the harsh and demeaning treatment the plaintiffs received while confined with 182 other detainees as "persons of high interest" in a special maximumsecurity facility after the $9 / 11$ attacks. ${ }^{21}$ With respect to the discrimination claims, ${ }^{22}$ the complaint alleged that the plaintiffs were detained and subjected to abusive treatment because of their race, religion, and national origin. ${ }^{23}$

The plaintiffs sued all those involved in some significant way, including John Ashcroft, former Attorney General of the United States, and Robert Mueller, Director of the FBI. The claims against Ashcroft and Mueller were not based on their direct involvement in the abusive treatment, but rather on their actions as supervisors of those who were directly involved. Ashcroft and Mueller (as well as other defendants) brought motions to dismiss under Rule 12(b) (6), relying on qualified immunity and arguing that the complaint failed to allege enough to support supervisory liability. ${ }^{24}$

20 Ashcroft v. Iqbal, 129 S. Ct. 1937, 1942-43 (2009). Javaid Iqbal, the only plaintiff remaining on appeal, was a Pakistani Muslim. Iqbal had been arrested on criminal charges before being specially detained. He eventually pled guilty, served his sentence, and was returned to Pakistan. He filed suit after he was back in Pakistan. Id. at 1943. The lawsuit is a Bivens action based on implied constitutional claims. See generally Bivens v. Six Unknown Named Agents of Fed. Bureau of Narcotics, 403 U.S. 388, 390-97 (1971) (recognizing implied constitutional claims).

21 See Elmaghraby v. Ashcroft, No. 04 CV 01809, 2005 WL 2375202, at *1-3, *6-8 (E.D.N.Y. Sept. 27, 2005). These detentions resulted from the massive FBI and Justice Department investigation in the wake of $9 / 11$. The FBI detained hundreds of individuals on immigration charges and then selected 184 as "persons of high interest" to be held in maximum security separate from the regular prison population. See id. at *1-2. The allegations of abusive treatment included severe verbal and physical abuse, unnecessary strip and body-cavity searches, denial of needed medical care, and unjustified interference with religious activities. $I d$. at *1, *6-8.

22 Insofar as constitutional claims are concerned, the plaintiffs also alleged violations of their First Amendment right to freedom of religion (based on interference with their religious activities as Muslims), their Fourth Amendment right to be free from unreasonable searches (based on the strip and body-cavity searches), their Fifth Amendment right to due process (based on the failure to provide hearings to determine whether continuing confinement was warranted), their Sixth Amendment right to counsel (based on the denial of access to lawyers), and their Eighth Amendment right to be free from cruel and unusual punishment. Id. at *7-9.

23 Id. at $* 3$, *8.

24 The qualified immunity doctrine insulates government officials from damages liability for constitutional violations unless they violate a clearly established constitutional right which they reasonably should have known. Also, supervisors cannot be held liable in Bivens suits for damages based on the doctrine of respondeat superior. See Iqbal, 129 S. Ct. at 1948. 
The district judge decided the motion prior to Twombly and thus applied pre-Twombly notice pleading law. The judge concluded that the complaint satisfied the pre-Twombly standard. ${ }^{25}$ Recognizing the special importance of minimizing litigation burdens on government officials with qualified immunity, ${ }^{26}$ however, the judge ordered staged and limited discovery and allowed Ashcroft and Mueller to file for summary judgment if early discovery returns failed to show a sufficient basis for supervisory liability. ${ }^{27}$

The defendants appealed the decision with respect to one of the plaintiffs, Javaid Iqbal, ${ }^{28}$ and the Second Circuit Court of Appeals affirmed the district court as to all claims except the procedural due process claim. ${ }^{29}$ The Second Circuit applied Twombly, which was decided while the case was on appeal, and concluded that Iqbal's allegations met the plausibility standard..$^{30}$ In particular, the Court found that the complaint alleged sufficient personal involvement to plausibly suggest supervisory liability for Ashcroft and Mueller:

[T] he complaint alleges broadly that Ashcroft and Mueller were instrumental in adopting the "policies and practices challenged here." The complaint also alleges that the FBI, "under the direction of Defendant Mueller," arrested thousands of Arab Muslims and that Ashcroft and Mueller "knew of, condoned, and willfully and maliciously agreed to subject Plaintiff[ ] to these conditions of confinement as a matter of policy, solely on account of [his] religion, race, and/or national origin and for no legitimate penological interest."... [T] he allegation that Ashcroft and Mueller condoned and agreed to the discrimination that the Plaintiff alleges satisfies the plausibility standard without an allegation of subsidiary facts because of the likelihood that these senior officials would have concerned themselves with the formulation and implementation of policies dealing with the confinement of those arrested on federal charges in the New York City area and designated "of high interest" in the aftermath of $9 / 11 . .^{31}$

25 Elmaghraby, 2005 WL 2375202 , at $* 11-12, * 28-29$.

26 Id. at $* 10-13$.

27 Id. at $* 21$.

28 Following the district judge's decision, the United States settled with the other plaintiff, Ehab Elmaghraby. See Iqbal v. Hasty, 490 F.3d 143, 147 (2d Cir. 2007), rev'd and remanded sub nom. Ashcroft v. Iqbal, 129 S. Ct. 1937 (2009).

29 Id. at 177-78. Although the court of appeals did not address the issue directly, the Supreme Court held that there was jurisdiction to consider the interlocutory appeal under the collateral order doctrine. See Iqbal, $129 \mathrm{~S}$. Ct. at 1945-47.

30 Iqbal, $490 \mathrm{~F} .3 \mathrm{~d}$ at $170,178$.

31 Id. at 175-76 (second and third alterations in original). 
The court recognized, however, that qualified immunity made it imperative to screen nonmeritorious suits as early as possible, especially in a case like Iqbal, involving senior government officials "against whom broad-ranging allegations of knowledge and personal involvement are easily made." 32 The district judge had fashioned a phased discovery plan to handle these concerns, and the court of appeals suggested some modifications. ${ }^{33}$

The Supreme Court reversed in a five-to-four decision. ${ }^{34}$ The opinion dealt only with Ashcroft and Mueller and focused on the discrimination claims. ${ }^{35}$ The majority first held that, as a substantive matter, supervisors like Ashcroft and Mueller asserting qualified immunity could not be held liable for their subordinates' discriminatory activities on principles of respondeat superior or merely on the basis of knowledge and acquiescence. ${ }^{36}$ Supervisory liability required proof that the supervisor himself acted with a discriminatory purpose, which in the Iqbal case meant that the plaintiff had to allege enough to show that Ashcroft and Mueller "adopted and implemented the detention policies at issue not for a neutral, investigative reason but

32 Id. at 159 ("Rule 8(a)'s liberal pleading requirement, when applied mechanically without countervailing discovery safeguards, threatens to create a dilemma between adhering to the Federal Rules and abiding by the principle that qualified immunity is an immunity from suit as well as from liability.").

33 The court of appeals suggested that the district judge start with interrogatories and requests to admit before deciding whether to allow depositions, and that he also focus discovery on the "front-line officials" before deciding whether to involve those higher up. Id. at 158.

34 Iqbal, $129 \mathrm{~S}$. Ct. at 1941 . The Court split along "conservative"/"liberal" lines, with Justices Souter, Breyer, Stevens, and Ginsburg dissenting. Rather than order the entry of a judgment of dismissal, however, the Court remanded to the court of appeals for it to decide whether to remand to the district court to allow the plaintiffs an opportunity to request leave to amend. Id. at 1954 . On July 28,2009 , the court of appeals decided to remand to the district court. See Iqbal v. Ashcroft, 574 F.3d 820, 822 (2d Cir. 2009). As of this writing, it appears that the case may have settled. See Arar v. Ashcroft, 585 F.3d 559, 585 n.8 (2d Cir. 2009) (Sack, J., concurring in part, and dissenting in part) ("On September 29, 2009, the remaining parties in Iqbal filed a document in this Court stipulating that the appeal was to be 'withdrawn from active consideration before the Court . . because a settlement has been reached in principle between Javaid Iqbal and defendant United States." (quoting Stipulation Withdrawing Appeal from Active Consideration, Iqbal v. Hasty, No. 05-5768-cv (2d Cir. Sept. 29, 2009)).

35 Shortly after this decision, the Court also granted certiorari and remanded as to several other defendants. See, e.g., Sawyer v. Iqbal, 129 S. Ct. 2431, 2431 (2009); Hasty v. Iqbal, 129 S. Ct. 2430, 2430 (2009).

36 Iqbal, 129 S. Ct. at 1948. 
for the purpose of discriminating on account of race, religion, or national origin." 37

The Court then turned to the pleading issue, whether the complaint adequately alleged Ashcroft's and Mueller's discriminatory purpose. The key allegations stated that Ashcroft and Mueller "'each knew of, condoned, and willfully and maliciously agreed to subject [the plaintiff]" to harsh conditions of confinement "'as a matter of policy, solely on account of [his] religion, race, and/or national origin and for no legitimate penological interest" and that Ashcroft was the "'principal architect" of this invidious policy and Mueller was "instrumental" in adopting and executing it. ${ }^{38}$

The Court evaluated the complaint by applying what it called a "two-pronged approach." 99 It first separated out the "legal conclusions," and then evaluated the remaining "factual allegations" to determine whether they supported a plausible inference of discriminatory purpose. ${ }^{40}$ The first prong of the analysis was decisive. The Court classified the key allegations described above as legal conclusions not entitled to the presumption of truth. ${ }^{41}$

With the key allegations out of the way, the second prong of the analysis proceeded smoothly. Although purposeful discrimination was a possibility, the majority held, the factual allegations plausibly showed only that Ashcroft and Mueller "sought to keep suspected terrorists in the most secure conditions available until the suspects could be cleared of terrorist activity." 42 Given who perpetrated the 9/11 attacks, this plan might well have had a disparate impact on Arab Muslims, but a disparate impact, the Court noted, is not enough to support a discriminatory purpose. ${ }^{43}$

$37 \quad I d$. at 1949.

38 Id. at 1944 (second alteration in original) (quoting First Amended Complaint at $\$ \S 10-11,96$, Elmaghraby v. Ashcroft, 2005 WL 2375202 (E.D.N.Y. Sept. 27, 2005) (No. 04 CV 01809)).

39 Id. at 1950.

40 Even if the majority rejects a liability standard based on knowledge plus deliberate indifference, as Justice Souter reads it to do, see id. at 1956-58 (Souter, J., dissenting), the Court's opinion still suggests that "some inference of wrongful intent" might be drawn from evidence that Ashcroft and Mueller "condoned" their subordinates' discriminatory treatment of detainees. Id. at 1952 (majority opinion).

41 Id. at 1951 ("These bare assertions, much like the pleading of conspiracy in Twombly, amount to nothing more than a 'formulaic recitation of the elements' of a constitutional discrimination claim . ..." (quoting Bell Atl. Corp. v. Twombly, 550 U.S. $544,555(2007))$.

$42 \quad I d$. at 1952.

43 Id. at 1951 ("It should come as no surprise that a legitimate policy directing law enforcement to arrest and detain individuals because of their suspected link to 
Justice Souter wrote a stinging dissent joined by Justices Breyer, Stevens, and Ginsburg. With regard to the pleading issue, ${ }^{44}$ Souter agreed that the complaint, stripped of its key allegations, would not meet a plausibility standard, but he strongly disagreed that the key allegations should be ignored as conclusory. ${ }^{45}$ If read in isolation, they might seem conclusory, Souter argued, but when read in the context of the complaint as a whole, they were quite specific. They alleged responsibility not for some "undefined" or "amorphous" discriminatory policy, but rather for a "particular, discrete, discriminatory policy" of detaining Arab Muslim men. ${ }^{46}$

It is highly significant that Justices Souter and Breyer dissented in Iqbal. Both were with the majority in Twombly. Moreover, Justice Souter, who wrote the principal dissenting opinion in Iqbal, actually authored the majority opinion in Twombly. These are strong signs that Iqbal is not just a straightforward application of Twombly.

\section{IQBAL's SIGNIFICANCE}

A. Old Ground: Twombly's Scope and the Efficacy of Case Management

Iqbal answers a question left in some doubt after Twombly: whether the plausibility standard applies beyond antitrust cases. The Iqbal Court held that it does. Now it is clear that the standard applies to all claims governed by Rule 8(a)(2)'s "short and plain statement" requirement. ${ }^{47}$

the attacks [of September 11] would produce a disparate, incidental impact on Arab Muslims, even though the purpose of the policy was to target neither Arabs nor Muslims.").

44 Justice Souter also takes the majority to task for its substantive holding, that supervisors can be liable only if they act with discriminatory intent themselves. Souter accuses the majority of reaching the substantive issue without crediting the defendants' concession that knowledge plus deliberate indifference would suffice and without the benefit of briefing and oral argument. See id. at 1956-58 (Souter, J., dissenting). But he also notes that the complaint without the key allegations would still be deficient under a knowledge and deliberate indifference standard. See id. at 1958.

45 See id. at 1960.

46 Id. at 1960-61. Justice Souter concluded that "[t]aking the complaint as a whole, it gives Ashcroft and Mueller 'fair notice of what the . . claim is and the grounds upon which it rests." Id. at 1961 (quoting Bell Atl. Corp. v. Twombly, 550 U.S. 544, 555 (2007)).

47 See id. at 1953 (majority opinion). This holding was hardly surprising. See Bone, supra note 7, at 881 (noting that lower courts have answered questions about the extent of Twombly's holding "in favor of a more general application"). 
Iqbal also reiterates Twombly's reservations about the efficacy of trial judge case management as a way to control discovery. ${ }^{48}$ Moreover, it relies on these reservations to justify rejecting discovery controls as a reason for leniency at the pleading stage. The Court might intend this principle to apply only to qualified immunity cases, but it uses language that suggests a broader application. ${ }^{49}$

\section{B. New Ground: Legal Conclusions Versus Factual Allegations}

Iqbal's novel doctrinal contribution is to subdivide the pleading analysis formally into two prongs, with the first prong sorting legal conclusions from factual allegations. The distinction between factual allegations and legal conclusions was an important feature of nineteenth century code pleading, but the Federal Rules of Civil Procedure eliminated it and, as I explain below, a notice pleading system has little use for it. ${ }^{50}$ The Iqbal Court breathes new life into the distinction and in so doing injects a highly problematic element into pleading analysis. 51

It is true that the Twombly Court relied on the same distinction to justify giving short shrift to general allegations of agreement in that case, but it did so in a very different way. ${ }^{52}$ In Twombly, the Court interpreted the complaint as a whole and concluded that a "fair reading" showed that the general allegations of agreement were intended to be conclusions based on parallel conduct alleged elsewhere in the complaint and thus not meant to add anything factually new. ${ }^{53}$ In Iqbal, by contrast, the Court deems the key allegations to be legal conclusions not because the plaintiff intended them so-he clearly did not-but because they just were so. ${ }^{54}$

The maiority in Iqbal is extremely unclear as to why these allegations were legal conclusions. It refers to the "tenet that a court must accept as true all of the allegations contained in a complaint" except for legal conclusions, and notes that Rule 8 "demands more than an

48 See Iqbal, $129 \mathrm{~S}$. Ct. at 1953 (referring to "[o]ur rejection of the careful-casemanagement approach").

49 See id. at 1954 ("Because respondent's complaint is deficient under Rule 8, he is not entitled to discovery, cabined or otherwise.").

50 See infra Part III.

51 For just a few examples of lower courts applying the two-pronged approach after Iqbal, see Maldonado v. Fontanes, 568 F.3d 263, 268 (1st Cir. 2009); Chao v. Ballista, 630 F. Supp. 2d 170, 177-79 (D. Mass. 2009); In re Novagold Res. Inc. Sec. Litig., 629 F. Supp. 2d 272, 284 (S.D.N.Y. 2009).

52 See Bell Atl. Corp. v. Twombly, 550 U.S. 544, 564 (2007).

53 See id.

54 See Iqbal, 129 S. Ct. at 1951. 
unadorned, the-defendant-unlawfully-harmed-me accusation."55 It then associates legal conclusions with " $t]$ hreadbare recitals of the elements of a cause of action, supported by mere conclusory statements" 56 and condemns the key allegations as "a "formulaic recitation of the elements' of a constitutional discrimination claim." 57

These statements point to some defect or deficiency intrinsic to the allegation itself. The reference to "formulaic recitation" and "an unadorned, the-defendant-unlawfully-harmed-me accusation" might suggest that the defect has to do with how closely the allegation tracks some standard way of expressing the legal element. For example, an allegation in Iqbal that "defendants intended to discriminate on account of race, religion, and national origin," without more, might be conclusory for this reason.

However, this cannot be the problem with the key allegations actually at issue in the case. The complaint alleged that the defendants "'knew of, condoned, and willfully and maliciously agreed to" impose harsh conditions on the plaintiff "'as a matter of policy, solely on account of [his] religion, race, or national origin and for no legitimate penological interest," and that Ashcroft was the "principal architect" of this policy and Mueller oversaw its execution. ${ }^{58}$ These statements describe mental states, link those mental states to a discriminatory policy described in some detail elsewhere in the complaint, and refer to more particular types of involvement by Ashcroft and Mueller. Admittedly, the mental states are described with conventional terminology used for that purpose (knew, condoned, and willfully and maliciously), but it is not clear what other language the plaintiff could have used and still conveyed his meaning clearly. ${ }^{59}$

The adjectives "unadorned," "threadbare" and "conclusory" suggest a different problem; not that the allegations track formulaic language, but that they state facts at too high a level of generality. ${ }^{60} \mathrm{~A}$

$55 I d$. at 1949.

$56 I d$.

57 Id. at 1951 (quoting Twombly, 550 U.S. at 555).

$58 I d$. at 1944 (alteration in original) (quoting First Amended Complaint, supra note $38, \$ \S 10-11,96$ ).

59 The words "know" and "condone," for example, are not just technical legal terms. They are part of ordinary vocabulary used to describe mental states, and their legal meaning depends to a large extent on their ordinary meaning. Thus, these words in the complaint convey factual information. Moreover, it is quite sensible in a situation like this for a pleader to use the same descriptors that the law employs in order to be clear about what is being alleged, especially since there are few, if any, alternatives available that convey the same meaning as clearly.

60 This would include statements that contain too much legal terminology and not enough factual content. The fatal defect in such an allegation cannot be its use of 
formulaic allegation is likely to be general, but a general allegation need not be formulaic. Justice Souter reads the majority to be saying this and counters by arguing that the key allegations are actually quite specific when read in the context of the Iqbal complaint as a whole. ${ }^{61}$

Justice Souter's argument highlights a serious difficulty with the degree-of-generality approach to distinguishing conclusions from facts. There is no obvious way to draw a line along the generalityspecificity continuum, and the Iqbal majority offers nothing to guide the analysis in a sensible way. To illustrate, consider the now-famous negligence allegation in Form 11 appended to the Federal Rules: "On date, at place, the defendant negligently drove a motor vehicle against the plaintiff." 62 Since the Forms are supposed to be sufficient, the Iqbal majority cannot classify this allegation as a legal conclusion. ${ }^{63}$ Yet it is difficult to see the difference between this negligence allegation and the key allegations in Iqbal. The Form 11 allegation says nothing about what the defendant's car was doing before it hit the plaintiff or why the plaintiff believes the defendant drove negligently. If anything, the key Iqbal allegations seem more specific. ${ }^{64}$

Lack of clarity about how to apply the first prong of the analysis is especially troubling because the classification of allegations as legal conclusions can be decisive. With the key allegations excluded in the first prong, the Iqbal majority, for example, had an easy time conclud-

legal terminology alone. It makes no sense to penalize a plaintiff for using legal terms if the allegation is otherwise factually sufficient. Therefore, the defect must have to do with the factual generality of the allegation.

61 See Iqbal, 129 S. Ct. at 1960-61.

62 FED. R. CIV. P. Form 11. Form 11 was made famous by Twombly, which, confusingly for some, approved the Form at the same time as endorsing the plausibility standard. Before the recent restyling amendments, Form 11 was Form 9 and included an actual date ("June 1, 1936"), an actual place ("in a public highway called Boylston Street in Boston, Massachusetts"), and an additional phrase at the end describing what the plaintiff was doing at the time ("who was then crossing said highway"). FED. R. Crv. P. Form 9 (2006) (repealed 2007).

63 See FED. R. Crv. P. 84 ("The forms in the Appendix suffice under these rules ....").

64 Justice Souter's treatment of the allegations in Iqbal provides another example. He argues that the key allegations are just as specific as other allegations the majority treats as factual. See Iqbal, $129 \mathrm{~S}$. Ct. at 1961 (Souter, J., dissenting). In particular, the allegation that "'[t]he policy of holding post-September-11th detainees in highly restrictive conditions of confinement until they were "cleared" by the FBI was approved by Defendants ASHCROFT and MUELLER in discussions in the weeks after September 11, 2001'" is, according to Souter, just as general as the key allegations that the majority condemns. Id. (quoting First Amended Complaint, supra note 38, §69). Therefore, if this allegation is factual, as the majority assumes, the key allegations must be factual too. See id. 
ing that the complaint failed the plausibility test in the second prong. Thus, the first prong did all the work.

\section{IQbal's Legal-Conclusion/FACTUAL-Allegation Distinction in Historical Context}

The history of the fact-law distinction in pleading sheds light on the problems with Iqbals two-pronged approach. The following account briefly describes the distinction in nineteenth century code practice, summarizes the legal realist critique of it in the early twentieth century, and recounts its fate when the Federal Rules of Civil Procedure were adopted in 1938.

\section{A. The Codes}

The typical nineteenth century procedure code required that the complaint contain "a plain and concise statement of the facts constituting each cause of action." 65 Over the course of the nineteenth century, judges interpreted this provision to require allegations of "ultimate facts" and to forbid "conclusions of law." 66

The requirement that a complaint focus on the facts was a critical part of the code reforms. The nineteenth century codes were a reaction to the hypertechnicality and perceived irrationality of the common law forms of action and common law pleading. ${ }^{67}$ A plaintiff bringing a suit at common law alleged formulaic legal language in order to fit his case into an established form of action, such as assumpsit, trover, trespass on the case, and so on. To the code reformers, this practice made no sense; it was part of an antiquated and irrational common law system rooted in a distant past. ${ }^{68}$ A rational legal system relied on a logical classification of abstract rights and remedies, not on arbitrary forms of action, and respected the fundamental distinction between law and fact. ${ }^{69}$ In such a system, the plaintiff alleged only the material, ultimate facts in her complaint and left it to the court to apply the law. ${ }^{70}$

65 Charles E. Clark, Handbook of the Law of Code Pleading 138 (1928).

66 See id. at 150, 153-55. Also, alleging "evidential facts" was forbidden, although this was considered a much less serious transgression than alleging a conclusion of law. See id. at 152-53.

67 See id. at 150.

68 See Robert G. Bone, Mapping the Boundaries of a Dispute: Conceptions of Ideal Lawsuit Structure from the Field Code to the Federal Rules, 89 CoLum. L. REv. 1, 21-22 (1989).

69 See, e.g., John Norton Pomeroy, Code Remedies $\$ \$ 407-23$ (5th ed. 1929).

70 See CLARK, supra note 65, at 2-3. For example, courts during the code period condemned as legal conclusions an allegation that the plaintiff as assignee was "holder" of a bond, that the defendant received money from the plaintiff "in trust" for 
The problems with the code approach are well known. It assumed that statements of fact and conclusions of law could be sharply distinguished; that "dry, naked, actual facts" could be reported without using legal concepts or legal language. ${ }^{71}$ When the legal realists criticized the code system in the early twentieth century, they attacked this assumption. The writings of Walter Wheeler Cook on the subject are particularly illuminating. ${ }^{72}$ According to Cook, the problem with the code's requirement lay "in the assumption that ... there is some clear, easily drawn and scientific distinction between socalled ... 'statements of fact' and 'conclusions of law,' whereas in truth there is none." 73 And this problem led to bad decisions and serious decisional inconsistency. ${ }^{74}$

Cook reasoned that while facts exist objectively, they cannot be stated without first filtering raw experience through a process of abstraction and classification. ${ }^{75}$ Moreover, since one always abstracts and classifies for a purpose, any statement of facts must employ concepts relevant to the purpose at hand. ${ }^{76}$

It followed for Cook that pleading facts for legal purposes naturally involves using legal concepts and categories. ${ }^{77}$ For example, an allegation that the defendant "had in his possession" certain items "belonging to the plaintiff" uses the technical legal concepts of "possession" and "belonging to." 78 Moreover, Cook argued, many allega-

certain purposes, and that the plaintiff was "entitled" to possession of certain property. See id. at 153-55 (giving these and numerous other examples).

71 Pomeroy, supra note $69, \S 423$, at 640 ("[T]he allegations must be of dry, naked, actual facts, while the rules of law applicable thereto, and the legal rights and duties arising therefrom, must be left entirely to the courts.").

72 See Walter Wheeler Cook, 'Facts' and 'Statements of Fact,' 4 U. CHI. L. Rev. 233, 239 (1936) [hereinafter Cook, Facts']; Walter Wheeler Cook, Statements of Fact in Pleading Under the Codes, 21 Colum. L. REv. 416, 417 (1921) [hereinafter Cook, Statements]; see also CLARK, supra note 65, at 155 ("But facts do not easily disentangle themselves from conclusions or from details.").

73 Cook, Statements, supra note 72 , at 417.

74 See ClaRK, supra note 65, at 153-55 (describing inconsistent results); see also 5 WRIGHT \& MILLER, supra note $16, \S 1218$, at 265 (noting the "evanescent judicial distinctions" and "ultimate calcification," as well as "traps for the unwary" and "tactical advantages" unrelated to the merits, that the code pleading rules created).

75 See Cook, 'Facts,' supra note 72, at 238-39 (noting that the process involves "select[ing] from among these infinitely varied aspects those which for some reason or other we are going to talk about" and then interpreting "the selected 'data' . . . so as to bring them under some category"); see also CLARK, supra note 65, at 155 (discussing the problem of disentangling facts and evidence).

76 See Cook, 'Facts,' supra note 72, at 239.

77 See id. at 241-43.

78 Id. at 243. 
tions condemned as conclusions of law are just as readily seen as general statements of fact. He illustrated with an allegation that the "defendant owes plaintiff $\$ 500$," which was usually treated as an impermissible conclusion of law under the codes. ${ }^{79}$ Cook pointed out that this allegation could be regarded "as a statement in generic form that all the facts necessary to create the legal duty to pay money described by the word 'owe' are true as between [the defendant and the plaintiff]." 80 Roughly speaking, factual allegations included legal content, and legal conclusions conveyed factual information.

Cook concluded from this analysis that there was no logical difference between permissible factual allegations and impermissible legal conclusions. ${ }^{81}$ The only relevant distinction was the degree of factual specificity. ${ }^{82}$ Conclusions of law were simply statements of fact pitched at too high a level of generality. Thus, the real question should be one of policy: How much factual particularity should be required "according to notions of fairness and convenience" considered in light of the goals that a pleading system should serve? ${ }^{83}$

There are two important lessons to draw from Cook's realist critique. First, the distinction between legal conclusions and factual allegations is necessarily a matter of degree rather than kind, and in particular depends on the degree of factual specificity. Second, any rule about what allegations are permissible and what are not must be justified on the basis of the policies a pleading system is supposed to serve. Both lessons will play a role in Part IV's critique of Iqbal.

\section{B. The Federal Rules of Civil Procedure}

Inspired by the legal realist critique and committed to liberalizing pleading practice, the drafters of the Federal Rules of Civil Procedure eliminated the code distinction between facts and legal conclusions. They did this by avoiding any mention of the word "fact" in the text of

79 Cook, Statements, supra note 72 , at 419.

80 Id.

81 See id. at 420.

82 See id. at 421; see also Cook, 'Facts,'supra note 72, at 244 (noting that the difference is "merely one of degree").

83 Cook, Statements, supra note 72, at 422 . Cook was firmly committed to notice pleading, so he advocated a pleading rule that required only as much specificity as was needed to give reasonable notice to the defendant and the court of "the real nature of the claim or defense." Id. He also strongly favored official forms as guides to pleading. See id. at 423; see also ClaAK, supra note 65, at 156-57 (focusing on the notice function); Cook, 'Facts,' supra note 72, at 245-46 (discussing the benefits of the forms). 
the new pleading rule. ${ }^{84}$ Their pleading rule, Rule $8(\mathrm{a})$, required only "a short and plain statement of the claim showing that the pleader is entitled to relief." 85

Indeed, a pure notice pleading system has little need for a distinction between legal conclusions and factual allegations. Charles Clark recognized this point when propounding the virtues of simplified notice pleading, ${ }^{86}$ and modern commentators agree. ${ }^{87}$ The question for notice pleading is whether the complaint, taken as a whole, gives fair notice of what the dispute is about. And to answer that question, one should consider everything the complaint says.

For example, a negligence complaint that says nothing more than "the defendant negligently hit the plaintiff and the plaintiff was injured as a result" would almost certainly be dismissed in a notice pleading system since it fails even to identify the events or incident that the plaintiff complains about. A court might describe a complaint like this as "conclusory" or say it states only "legal conclusions." 88 As long as the judge faithfully adhered to the goal of giving notice, however, these labels could add nothing to the analysis. "Conclusory," "legal conclusion" and the like are simply ways to express a prior determination that the complaint does not convey enough information to give fair notice to the defendant.

84 Charles Clark, the chief architect of the Federal Rules, put it this way:

By omitting any reference to "facts" the Federal Rules have avoided one of the most controversial points in code pleading. As Professor Moore has so aptly stated, "The federal courts are not hampered by the morass of decisions as to whether a particular allegation is one of fact, evidence, or law." This departure from the traditional code-pleading requirement has been liberally applied by the courts and lauded by the legal writers.

Charles E. Clark et al., Handbook of the Law of Code Pleading 242-43 (2d ed. 1947) (footnotes omitted) (quoting 1 James WM. MoOre ET al., MoOrE's Federal Practice 553 (1938)); see also Edson R. Sunderland, The New Federal Rules, 45 W. VA. L.Q. 5, 12 (1938) (noting that the FRCP eliminate any mention of facts because "courts have been trying for five hundred years to find 'facts' and nobody has ever been able to draw a line between what were and what were not 'facts'").

85 FED. R. Crv. P. 8(a) (2). For the code provision, see supra note 65 and accompanying text.

86 See ClaRk, supra note 84, at 241-45.

87 See 5 Wright \& Miller, supra note $16, \S 1218$; see also 2 JAMEs WM. MOORE ET al., Moore's Federal Practice $\$ 8.04$ (2), at 35 (3d ed. 2009) (stating that conclusory allegations are permitted by the Federal Rules, but "sufficient factual allegations must be pleaded along with the conclusions of law to give fair notice to the opposing party").

88 See, e.g., Carr v. Sharp, 454 F.2d 271, 273 (3d Cir. 1971); Magellan Int'l Corp. v. Salzgitter Handel GmbH, 76 F. Supp. 2d 919, 927 (N.D. Ill. 1999). 
Nevertheless, even during the heyday of notice pleading under the Federal Rules, courts used the distinction between legal conclusions and factual allegations for some pleading purposes. ${ }^{89}$ The complaint had to relate facts that at least loosely fit the elements of some legal theory, and the plaintiff was not allowed to fill gaps with conclusory assertions or general allegations that contradicted the rest of the complaint. ${ }^{90}$ Today, it is settled law that a judge deciding a 12(b) (6) motion need not accept legal conclusions or conclusory allegations as true. ${ }^{91}$

These rules most likely reflect the influence of a weak screening policy. Notice pleading was mostly about giving notice, but judges must have been reluctant-and understandably so-to let a lawsuit go forward when it was patently obvious the plaintiff had no legal claim and was desperately trying to fill holes with general statements. ${ }^{92}$ If the judge had to accept a general statement at face value, such as "the defendant acted negligently," without any other factual support, there would be no way to dismiss a lawsuit that obviously should be dismissed. ${ }^{93}$

89 See, e.g., 5B WRIGHT \& MILLER, supra note 16, § 1357, at 544 ("This occasional judicial reliance on some of the nomenclature of the code pleading regime, such as 'facts' and 'conclusions,' reflects the difficulty of phrasing in abstract terms a rule of construction of pleadings that is relatively simple in actual operation.") (footnotes omitted).

90 Id. $\$ 1357$, at $544-553$ (" $[\mathrm{M}]$ any federal courts have made it clear that more detail often is required than the bald statement by the plaintiff that she has a valid claim of some legally recognizable type against the defendant. ... [T] he court will not accept conclusory allegations concerning the legal effect of the events the plaintiff has set out if these allegations do not reasonably follow from the pleader's description of what happened, or if these allegations are contradicted by the description itself.") (footnotes omitted).

91 Or inferences that do not reasonably follow from or are contradicted by more detailed descriptions in the complaint. See id.; 2 MoORE, supra note 87, §12.34(1) (b).

92 Of course, a 12(b) (6) motion is always available to dismiss a suit when there is no claim as a matter of law that could give the plaintiffs the relief they seek. For example, a plaintiff might tell a detailed story about how his teacher's awful teaching methods ruined his life, but the complaint will still be dismissed because there is no claim for ordinary educational malpractice. See, e.g., Vill. Cmty. Sch. v. Adler, 478 N.Y.S.2d 546, 547 (City Civ. Ct. 1984). The situation that concerns us is very different from this. Our focus is on cases in which there is a recognized legal claim but the plaintiff has not adequately alleged it.

93 I focus here on the golden age of notice pleading during the 1960s and 1970s. It is worth mentioning, however, that starting in the early $1980 \mathrm{~s}$, federal judges began to impose stricter requirements in an effort to screen frivolous suits in some types of cases, and some judges continued to do so despite contrary Supreme Court holdings. See Swierkiewicz v. Sorema N.A., 534 U.S. 506, 510-15 (2002); Leatherman v. Tarrant County Narcotics Intelligence \& Coordination Unit, 507 U.S. 163, 167-69 (1993). It 
Still, the question remains: What distinguishes a legal conclusion from a factual allegation, especially when the allegation in question, like the key allegations in Iqbal, includes substantial factual content? ${ }^{94}$ The answer in Part IV shows why Iqbal's two-pronged approach is incoherent.

\section{IQbal Critiqued}

The following critique of Iqbal focuses on two problematic features of the Court's analysis. First, the two-pronged approach is incoherent. Second, the Court adopts a stricter version of the plausibility standard than Twombly did, and this reflects a more aggressive approach to screening at the pleading stage. This aggressive approach is not appropriate for many cases, and in any event, it is not something that the Court should be implementing on its own.

\section{A. The Two-Pronged Approach: One Prong, Not Two}

As Twombly made clear, the plausibility standard is meant to screen meritless suits, not just give fair notice to the defendant. ${ }^{95}$ Screening requires a critical approach to allegations. To be sure, a judge cannot ignore an allegation solely because she happens to doubt the truth of what it says. ${ }^{96}$ But she also cannot accept every allegation at face value and still be able to screen lawsuits. ${ }^{97}$

would not be surprising if these judges used the legal-conclusion/factual-allegation distinction more aggressively during this later period.

94 The legal-conclusion/factual-allegation dichotomy would be relatively easy to apply in practice if the category "legal conclusion" were limited to allegations that simply insert "plaintiff" and "defendant" into a legal proposition otherwise stated in some recognizably canonical form. Examples might include "the defendant acted negligently" when the claim is for negligence, or "the defendants conspired" when the claim is for an antitrust conspiracy. If legal conclusions were limited to this type of statement, however, the dichotomy would do little work as a practical matter. The key Iqbal allegations, for instance, are not straightforward canonical statements of the law. They allege knowledge and other states of mind linked to a discriminatory policy described in some detail elsewhere in the complaint and even refer to more particular types of involvement by Ashcroft and Mueller. See supra note 59 and accompanying text.

95 See Bell Atl. Corp. v. Twombly, 550 U.S. 544, 557-60 (2007).

96 See Neitzke v. Williams, 490 U.S. 319, 327 (1989) ("What Rule 12(b) (6) does not countenance are dismissals based on a judge's disbelief of a complaint's factual allegations. District court judges looking to dismiss claims on such grounds must look elsewhere for legal support.").

97 In Twombly, for example, the complaint stated that the defendants "have entered into a contract, combination or conspiracy to prevent competitive entry in to their ... markets and have agreed not to compete with one another." Twombly, 550 
The challenge, however, is to define those allegations that should not be accepted at face value. In other words, what is it about an allegation that makes it a legal conclusion? Walter Wheeler Cook had the answer almost a century ago. ${ }^{98}$ Contrary to the arguments of some commentators, ${ }^{99}$ what qualifies an allegation as a "legal conclusion" or as too "conclusory" is not that it tracks the elements of a legal claim too closely. ${ }^{100}$ Rather it is that the allegation states facts at too high a level of generality. But when are allegations too general in this sense? As Cook correctly noted, the answer is when greater specificity is required to serve the policy goals of pleading. ${ }^{101}$ The goal of providing notice is consistent with very general allegations, as Cook and Clark both understood. ${ }^{102}$ However, a screening goal requires greater specificity. The requisite level of specificity is set by the strictness of the pleading standard, which in turn reflects a policy decision about how much screening is optimal at the pleading stage.

This means that allegations are too general-and thus qualify as "legal conclusions" or are too "conclusory"-when they fail to meet the pleading standard. But it is the complaint as a whole that must meet the standard, not each individual allegation taken separately. The fact that one allegation is extremely general should not matter as long as other allegations fill in the necessary detail. Moreover, the complaint is not just a list of individual allegations. The complaint is supposed to give a coherent account of the relevant events and transactions involved in the dispute. Therefore, it must be interpreted as a

U.S. at 565 (quoting Complaint at II 51, Twombly v. Bell Atl. Corp., 313 F. Supp. 2d 174 (S.D.N.Y. 2003) (No. 02 Civ. 10220)). If the Court had to accept all allegations as true, it would have had no choice but to conclude that a plausible claim of conspiracy was stated.

98 See generally supra notes 72-83 and accompanying text (discussing Cook's realist critique).

99 See, e.g., Edward A. Hartnett, Taming Twombly, Even After Iqbal, 158 U. PA. L. Rev. 473, 491-494 (2010).

100 Not only does one need a definition of "too closely" to make this formulation work, but more importantly, there is no sensible reason why the amount of legal content alone should make the difference and therefore no policy to guide determinations of what is "too close."

101 See Cook, Statements, supra note 72, at 422-23 (describing how much factual particularity should be required "according to notions of fairness and convenience" considered in light of the goals that a pleading system should serve).

102 See CLARK, supra note 65, at 157 (noting that "generalities of allegation should not be objectionable in themselves, so long as reasonably fair notice of the pleader's cause of action is given."); Cook, Statements, supra note 72, at 422-23 (noting that only as much specificity is needed to give reasonable notice to the defendant and the court of "the real nature of the claim or defense"). 
coherent whole, and the sufficiency of its allegations must be evaluated in a holistic way.

The Twombly Court understood this point clearly. It did not simply dismiss the questionable allegations of agreement as conclusory and then subject the remaining allegations to the plausibility standard, as the Iqbal Court claims it did. Instead, it interpreted the complaint as a whole, and based on that interpretation, determined that the questionable allegations were intended to be conclusions and not to add any new facts to the complaint. ${ }^{103}$ Justice Souter also understood this fundamental point in his Iqbal dissent. He interpreted the key allegations in the context of the complaint as a whole before concluding that the plausibility standard was met. ${ }^{104}$

It follows from the holistic nature of pleading analysis that there is no conceptual distinction between the two parts of Iqbal s two-pronged approach. The second prong is all there is to a pleading analysis. It makes no sense first to exclude certain allegations as conclusory on account of their generality and then to subject the remaining allegations to the pleading standard. The reason certain allegations are conclusory is that the complaint, interpreted with them in it, does not meet the pleading standard for the legal element the defective allegations are meant to support. For example, if the key allegations in the Iqbal complaint are conclusory, it is not because of some defect in the allegations themselves, but because the complaint that includes them, when interpreted as a whole, tells a story that does not plausibly support Ashcroft and Mueller having a discriminatory purpose.

This insight is important. The two-pronged approach facilitates overly aggressive screening at the pleading stage. A judge bent on screening aggressively does not have to work as hard to apply the plausibility standard if she can classify problematic allegations as legal conclusions and eliminate them at the initial stage. It should be more difficult for the judge to justify her decisions if she cannot get rid of pesky allegations so easily and instead must explain why the best interpretation of the complaint taken as a whole, with all the allegations included, does not meet the plausibility test. I do not mean to suggest that judges always explain their pleading decisions carefully. Still, framing pleading doctrine as a single prong should encourage lawyers

103 See supra notes 52-53 and accompanying text.

104 Ashcroft v. Iqbal, 129 S. Ct. 1937, 1961 (2009) (Souter, J., dissenting) (“Taking the complaint as a whole, it gives Ashcroft and Mueller 'fair notice of what the . . claim is and the grounds upon which it rests." (quoting Bell Atl. Corp. v. Twombly, 550 U.S. 544, 555 (2007) (alteration in original))). 
to structure their arguments properly and judges to approach the analysis in the right way. ${ }^{105}$

\section{B. The Strictness of the Pleading Standard}

There is a deeper and more serious problem with Iqbal. The majority applies a stricter pleading standard than the Court did in Twombly, one that reflects an implicit policy judgment that pleadings should be used to screen suits more aggressively. Eliminating the key allegations before applying the plausibility standard obscures this point. But the difference is significant, and it is crucially important.

To state this point more precisely, it is helpful to distinguish between two screening approaches. One approach, which I shall call the "thin screening model," assumes that the only appropriate screening function at the pleading stage is to screen truly meritless suits. By a "truly meritless suit," I mean a lawsuit in which the defendant is clearly not liable as an objective matter. ${ }^{106}$ This includes cases in which liability turns on objective facts about the defendant's conduct and the defendant in fact did not act in the required way. It also includes cases, such as those seeking to recover for negligence, in which liability depends on a judgment about the quality of the defendant's conduct relative to a standard, such as unreasonableness, and the defendant's conduct falls so far short of the liability standard that no jury could properly find him liable. ${ }^{107}$ A pleading rule based on this model requires greater factual specificity only when specificity is necessary for the judge to be sufficiently confident that the suit is not meritless.

The other approach, which I shall call the "thick screening model," enlists pleading more aggressively. It targets not only clearly meritless suits, but also suits that might merely be described as weak but that are not meritless (i.e., suits with too low a probability of trial success). An example is a negligence case in which the defendant's conduct is within the range that a jury could properly deem unreason-

105 It is worth emphasizing that the discussion in the text focuses on pleading. The fact-law dichotomy operates in other legal contexts, such as dividing decisionmaking responsibility between judge and jury and defining the scope of appellate review. The dichotomy has a core of meaning that is useful in each of these contexts, and as in pleading, its application to grey areas depends on the distinctive policies at stake.

106 I develop this definition more fully in Bone, supra note 7, at 916-19. See also Robert G. Bone, Modeling Frivolous Suits, 145 U. PA. L. Rev. 519, 529-33 (1997) (discussing the problem of defining a "frivolous suit" and offering a definition that depends on the idea of a suit lacking merit as an objective matter).

107 See Bone, supra note 7, at 917. 
able (thus making the suit meritorious not meritless), but just barely within that range so a liability judgment at trial is highly unlikely (thus making the suit weak). There are stricter and more lenient versions of thick screening depending on where the merits threshold is set. And even a relatively high threshold might be justified on efficiency grounds, as necessary to assure that scarce litigation resources are invested in strong enough cases to reap social benefits that exceed the social costs. ${ }^{108}$

Framed in these terms, my point is that Twombly implements a thin screening model, while Iqbal implements a thick screening model. The two models differ in theory, support different pleading standards, and invite different attitudes toward screening. Many commentators lump Iqbal and Twombly together. ${ }^{109}$ They treat Iqbal as just another application of Twombly, one in which the plausibility standard is applied outside the antitrust field. This is a mistake. Iqbal's screening approach is qualitatively different than Twombly's, and it is important to understand the differences in order to appreciate Twombly's virtues distinct from Iqbal s vices.

The following discussion describes the two screening models in more detail and explains why the thick screening model fits Iqbal and the thin screening model fits Twombly. It relies on inferences from the way the Court applies the plausibility standard in each case and on contrasting language in the two opinions. ${ }^{110}$

\section{Iqbal and the Thick Screening Model}

The thick screening model explains Iqbal's insistence on greater factual specificity for allegations about Ashcroft's and Mueller's states of mind and fits the language it uses to justify its holding. To see the first point, consider a pleading system that adopts the thick screening model and aims to screen weak cases as well as meritless ones. Suppose the system takes a rather aggressive approach to screening and

108 See, e.g., Keith N. Hylton, When Should a Case be Dismissed? The Economics of Pleading and Summary Judgment Standards, 16 SuP. CT. ECon. Rev. 39, 41 (2008) ("In general, pleading standards should vary with the evidentiary demands of the associated legal standards and the social costs of litigation.").

109 See, e.g., Hartnett, supra note 99 (manuscript at 17-18); Adam N. Steinman, The Pleading Problem, 62 STAN. L. Rev. (forthcoming 2010) (manuscript at 24-35), available at http://papers.ssrn.com/sol3/papers.cfm?abstract_id=1442786 (deriving pleading principles from Twombly and Iqbal treated as mutually consistent decisions). 110 Distinguishing different levels of screening and pleading strictness through case interpretation is a tricky business. The flexibility and open-ended nature of the plausibility concept only compounds the problem by making it more difficult to nail down precisely how the concept is being applied. 
seeks to screen cases that do not have at least a moderate chance of success at trial (say, somewhere around a thirty to forty percent chance of success).111 A judge would need to know quite a bit about the facts before she could be confident that a particular case was at least that strong. As a result, we would expect the pleading standard to be fairly strict and require rather specific allegations for each element. ${ }^{112}$

More precisely, allegations are too general in this pleading system when they do not reveal enough about the case to show how the plaintiff might prove liability at trial. For example, suppose the plaintiff brings a negligence suit and alleges that "on June 1, 2008, the defendant, while driving his car down Beacon Street in Boston, Massachusetts, negligently struck the plaintiff, who was walking across the street."113 This allegation certainly suggests negligence, even without the adverb "negligently." After all, pedestrians are not usually struck by cars unless the driver fails to use reasonable care. But the allegation is not specific enough to instill confidence that the case has a moderate chance of trial success. To be sure, a judge could be reasonably confident that the plaintiff would be able to prove that she was struck on Beacon Street by a car, that the car was driven by the defendant, and that the plaintiff was walking across the street at the time. ${ }^{114}$ All of these are objectively verifiable facts likely to have been observed by witnesses-and some by the plaintiff herself-and perhaps even included in a police report. However, these facts are not enough alone. There are just too many non-negligent ways that the plaintiff might have been struck. For example, the defendant's car might have slid on an oil slick that was not detectable by a reasonably careful driver, or the plaintiff might have recklessly jaywalked.

111 Of course, the judge is likely to conceive of a merits threshold in rough qualitative terms rather than numerical probabilities. It is worth mentioning that two commentators have argued for a fifty percent probability cutoff. See Warren F. Schwartz \& C. Frederick Beckner III, Toward a Theory of the "Meritorious Case": Legal Uncertainty as a Social Choice Problem, 6 Geo. Mason L. Rev. 801, 816-19 (1998).

112 By contrast, if the decision is to screen only cases that are virtually certain to lose, the judge would need less factual detail to make the necessary determination, and as a result the pleading standard would tolerate allegations at a higher level of generality.

113 This allegation is based on, but a bit more detailed than, the allegation in Form 11 appended to the Federal Rules of Civil Procedure. See Fed. R. Crv. P. Form 11. In fact, it is very similar to the original Form 9 version before the restyling amendments. See supra note 62 and accompanying text.

114 To be sure, the plaintiff states that the defendant acted "negligently," but negligence is something that must be proved by showing more specific facts. 
Thus, more specific facts are needed before the judge can make the requisite assessment of trial success. It might be enough, for example, if the plaintiff also alleged that the defendant's car was speeding and that the plaintiff was crossing the street on a green light and in the sidewalk. These additional facts, like the others alleged, are objectively verifiable and likely to have evidentiary support in an automobile negligence case. This is not to say, of course, that the plaintiff will actually be able to prove them. That depends on the admissible evidence and is not a matter for determination at the pleading stage. The assessment of likely trial success that the thick screening model requires is an all-things-considered prediction based on what the complaint tells the judge about the facts and what the judge knows from her experience about how facts like the ones alleged are usually proved in similar cases. ${ }^{115}$

All the previous examples involve facts that are, in theory at least, objectively verifiable and in a relatively straightforward way. However, facts that are difficult to verify objectively fare much worse in a thick screening model. Two notable examples are the types of factual allegations at issue in Iqbal and Twombly: descriptions of the defendant's state of mind (e.g., Iqbal's allegations of knowledge, condoning, willfulness and malice relevant to discriminatory intent), and references to actions taken in private (e.g., Twombly's allegation of an agreement). This type of information is often within the exclusive knowledge of the defendant and the plaintiff will usually have considerable difficulty learning much about it before filing. As a result, general allegations merely reciting the existence of a state of mind or a private action are not likely to instill much confidence that the plaintiff will be able to prove those allegations at trial. So it makes sense for a judge in our hypothetical, seeking to determine whether the suit has a moderate chance of trial success, to demand that the plaintiff show more support in the complaint. And the plaintiff does this by alleging supporting facts that are more specific and more easily verified objectively.

Thus, the reason why a judge applying a thick screening model ${ }^{116}$ would find the allegations in Iqbal and Twombly insufficient and clas-

115 See Ashcroft v. Iqbal, 129 S. Ct. 1937, 1940 (2009) (“[D]etermining whether a complaint states a plausible claim is context-specific, requiring the reviewing court to draw on its experience and common sense.").

116 This is not the reason the Twombly Court actually gave for treating the general allegations of agreement as conclusory. Rather the Court reasoned that the best interpretation of the complaint as a whole showed that these allegations were meant to be conclusions. See supra notes 52-53 and accompanying text. That is not surprising because the Twombly Court did not apply a thick screening model. See infra Part 
sify them as conclusory is because the facts they allege are very likely to be the private information of the defendant, so the judge cannot be confident enough of trial success without more supporting detail. ${ }^{117}$ To crystallize this point, it is useful to contrast an ordinary breach of contract suit between two contracting firms in which the plaintiff alleges that "the parties entered into an agreement by which the plaintiff promised to sell and the defendant to buy widgets." This allegation is as general as the one in Twombly, but there is an important difference. The plaintiff was a party to the agreement and this gives her direct access to specific factual support. Indeed, the plaintiff's employees are likely to have direct knowledge of the transaction and can testify to it at trial. Thus, the judge has reason to be more confident here than in Twombly that the plaintiff will be able to prove the existence of an agreement, and as a result the judge should be much less inclined to demand greater factual specificity. ${ }^{118}$

This interpretation of Iqbal explains why the Court demands greater specificity for the mental-state allegations in the complaint. ${ }^{119}$

IV.B.2., where I consider how allegations like these would be treated in a thin screening model.

117 Requiring more detail for facts that are private information of the defendant puts the plaintiff in a kind of Catch-22. She must allege more detail before discovery, but the detail she must allege is very difficult to obtain without discovery. This feature of the problem means that the thick screening model risks high social costs by screening strong meritorious suits as well as weak ones. See infra Part IV.C.

118 The judge might still demand more facts, however, if the merits threshold were set very high.

119 It is significant, I believe, that many cases decided after Iqbal classify allegations as conclusory when they involve state of mind or other private information that is likely to be proved circumstantially and the plaintiff does not allege enough of the circumstantial facts. See Cafaro v. HMC Int'l, LLC, No. 07-2793, 2009 WL 1622825, at *3-5 (D.N.J. June 10, 2009) (finding that statements alleging defendant "knowingly and substantially assisted" another party's wrongdoing and was "actually . . aware" of the wrongdoing were conclusory); Halderman v. City of Iberia, No. 09-4049-CV, 2009 WL 1912531, at *2 (W.D. Mo. June 1, 2009) (finding allegation of conspiracy conclusory and unsupported by factual allegations); Mohammad v. N.Y. State Higher Educ. Servs. Corp., No. 08-CV-4943, 2009 WL 1514635, at *4 (E.D.N.Y. June 1, 2009) (finding statements that collection actions reinitiated after twenty years were resumed due to plaintiff's race conclusory and unsupported by accompanying factual allegations). But see Tyree v. Zenk, No. 05-CV-2998, 2009 WL 1456554, at *7 (E.D.N.Y. May 22, 2009) (applying Iqbal to conclude that circumstantial evidence of defendants being in cahoots meets plausibility requirement with factual allegations). Admittedly, and as Justice Souter recognizes, the Iqbal majority accepts some general allegations that seem rather similar to the state-of-mind allegations it rejects. In particular, the Court accepts as true the allegation that " $[t]$ he policy of holding post-September11 th detainees in highly restrictive conditions of confinement until they were "cleared" by the FBI was approved by Defendants ASHCROFT and MUELLER in dis- 
Moreover, it provides a rigorous framework for understanding what seems obvious when reading the opinion, that the Court is more demanding than it was in Twombly. And it also accounts for particular language in the opinion. For example, Iqbal frames the plausibility inquiry as inferring liability from facts in a way that evokes the jury's function at trial: "A claim has facial plausibility when the plaintiff pleads factual content that allows the court to draw the reasonable inference that the defendant is liable for the misconduct alleged."120 The Court cites Twombly to support this formulation, ${ }^{121}$ but Twombly never stated the standard in such strong terms. Instead, Twombly used softer language, employing the word "suggest" throughout the opinion: The allegations must "suggest that an agreement was made."122

To be sure, Iqbal mentions that "the plausibility standard is not akin to a "probability requirement,"' but it does so only in passing as part of a boilerplate summary of the doctrine. ${ }^{123}$ By contrast, Twombly emphasizes repeatedly that it does not require a likelihood of trial success and that a lawsuit can go forward even if the judge believes that the facts alleged are "improbable." 124 And Justice Souter makes a

cussions in the weeks after September 11, 2001." Iqbal, 129 S. Ct. at 1951 (alteration in original) (quoting First Amended Complaint, supra note 38, 69). This allegation refers to private information of the defendants, so one might have expected the Court to demand more factual support if $I$ am correct about its applying a thick screening model. However, three points are critical. First, the allegation is difficult to label as a "legal conclusion" because what it says is not closely enough connected to a legal element (although it might still be characterized as too "conclusory"). While all legal conclusions are general factual allegations, not all general factual allegations can be classified as legal conclusions. Second, unlike the allegation of agreement in Twombly, this allegation rings true on its face. It would have been reasonable for Ashcroft and Mueller to approve a policy of restrictive confinement given the $9 / 11$ events. Third, it is easier to imagine how this allegation would be proved than it is to imagine how the mental-state allegations in the Iqbal complaint would be proved.

120 Iqbal, $129 \mathrm{~S}$. Ct. at 1949 (emphasis added).

121 Id.

122 Twombly, 550 U.S. at 556 (emphasis added). I count no fewer than seven places in the opinion where the Court uses the word "suggest" or a variation to state the plausibility standard. See id. at 556 ("suggest"), 557 ("suggestion," "plausibly suggesting," and "suggesting"), 562 ("suggests"), 566 ("plausible suggestion"), 569 ("suggested"). The Court also notes that the standard, rather than imposing a probability of success requirement, "simply calls for enough fact to raise a reasonable expectation that discovery will reveal evidence of illegal agreement." Id. at 556 . This passage does refer to a reasonable expectation, but the expectation is about discovery, not liability. And the fact that the Court juxtaposes it to the probability of trial success sharpens the contrast.

123 See Iqbal, 129 S. Ct. at 1949 (quoting Twombly, 550 U.S. at 556).

124 Twombly, 550 U.S. at 556 (noting that "a well-pleaded complaint may proceed even if it strikes a savvy judge that actual proof of the facts alleged is improbable, and 
point of recalling this portion of the Twombly opinion when criticizing the majority in his Iqbal dissent. ${ }^{125}$

\section{Twombly and the Thin Screening Model}

In my previous article, I argued that the best reading of Twombly is that the Court means to screen only suits that are truly meritless. ${ }^{126}$ In keeping with this goal, the plausibility standard functions as an epistemological rather than a merits threshold. ${ }^{127}$ In other words, plausibility refers not to the likelihood of success at trial, but rather to a threshold level of confidence a judge must have that the lawsuit is not meritless. Thus, a judge should not dismiss if she is convinced that it is at least plausible that the suit is meritorious even if she also believes that it will very likely lose at trial.

I also argued that Twombly set a relatively low confidence threshold. A complaint is sufficient if the story it tells differs significantly from what is treated as the normal baseline state of affairs associated with lawful conduct, and in a way that suggests illegality. ${ }^{128}$ The Twombly complaint failed to meet this standard because the parallel conduct it described was exactly what one would expect from a vigorously competitive telecommunications market. In other words, the story the complaint told was just the normal baseline of competitive activity in that market. ${ }^{129}$

To be sure, the conduct alleged might possibly have been the result of illegal agreement; after all, what seems perfectly ordinary sometimes involves illegality. But plaintiffs have to allege some facts that at least "suggest" as much. ${ }^{130}$ Otherwise, there would be no way to screen meritless suits at the pleading stage. Virtually anyone could sue by alleging perfectly ordinary conduct and arguing that there is always a possibility of wrongdoing even under ordinary circumstances.

Thus, Twombly uses a thin screening model with a low confidence threshold. Had the Iqbal Court used the same model, it would have had much more difficulty holding as it did. With the key allegations included, the best interpretation of the Iqbal complaint is that it tells a highly unusual story-the story of $9 / 11$ and its aftermath-that differs

'that a recovery is very remote and unlikely." (quoting Scheuer v. Rhodes, 416 U.S. 232, 236 (1974))).

125 See Iqbal, 129 S. Ct. at 1959 (Souter, J., dissenting).

126 Bone, supra note 7, at 918-19.

127 See id. at 918.

128 See id. at $885-88$.

129 See id. at 884-85.

130 See Bell Atl. Corp. v. Twombly, 550 U.S. 544, 555 (2007); id. at 561-62 (" [T] he complaint does not set forth a single fact in a context that suggests an agreement."). 
sharply from what is normal for officials conducting investigations and detaining suspects; in other words, from the ordinary baseline for investigation and detention activities. ${ }^{131}$ Moreover, interpreted against the background circumstances-just as the Twombly' Court interpreted the allegations of parallel conduct in that case ${ }^{132}$ - the story the complaint tells differs from the baseline in ways that at least "suggest" knowledge, condoning, and perhaps even more direct involvement on the part of Ashcroft and Mueller in discriminatory conduct by lower level officials. As the Iqbal court of appeals correctly observed, "the likelihood that [Ashcroft and Mueller] would have concerned themselves with the formulation and implementation of policies dealing with the confinement of those arrested on federal charges in the New York City area and designated 'of high interest' in the aftermath of 9/11"133 makes it plausible that they would have "condoned and agreed to the discrimination."134

Put simply, the Iqbal complaint tells a story that is unusual enough to suggest something fishy might be going on. To use the language of Twombly, the allegations are "enough to raise a right to relief above the speculative level." 135 Of course, the plaintiff might have great difficulty proving discriminatory intent at trial-mental states are notoriously hard to prove-and his complaint offers little reassurance that he will be able to do so. This, I believe, is the reason the Iqbal majority found the complaint insufficient. But Twombly did not demand any particular likelihood of trial success, just a narrative that significantly differs from the ordinary state of affairs. ${ }^{136}$ Trial suc-

131 Within the ordinary baseline of investigation and detention activities, it is reasonable to assume that government officials almost always behave responsibly and lawfully.

132 See Twombly, 550 U.S. at 564-69 (taking account of publicly available background information about the history and structure of the telecommunications market).

133 Iqbal v. Hasty, 490 F.3d 143, 175-76 (2d Cir. 2007), rev'd and remanded sub nom. Ashcroft v. Iqbal, 129 S. Ct. 1937 (2009).

134 Id. at 175; see also id. at 166 ("Even as to Ashcroft and Mueller, it is plausible to believe that senior officials of the Department of Justice would be aware of policies concerning the detention of those arrested ... in the aftermath of $9 / 11$ and would know about, condone, or otherwise have personal involvement in the implementation of those policies."). For endorsement of the court of appeals' analysis on similar grounds, see Stephen B. Burbank, Pleading and the Dilemmas of "General Rules," 2009 WIS. L. REv. 535, 556-57.

135 Twombly, 550 U.S. at 555.

136 See id. at $557 \mathrm{n} .5$ (stating that the plausibly standard marks a line "between the factually neutral and the factually suggestive"); see also Ashcroft, 129 S. Ct. at 1960 (Souter. J., dissenting) (stating that in Iqbal, by contrast to Twombly, "the allegations in the complaint are neither confined to naked legal conclusions nor consistent with legal 
cess is for the thick screening model, which is what the Iqbal Court uses. $^{137}$ Twombly, however, applies a thin screening model.

\section{Problems With Thick Screening and Strict Standards}

A thick screening model with a strict pleading standard is highly problematic. ${ }^{138}$ Strict pleading can produce screening benefits for some cases, but it does so in a relatively crude way and at an uncertain and potentially high cost. The most serious cost involves screening meritorious suits. In cases like Iqbal, where the defendant has critical

conduct" and concluding that the Iqbal "complaint therefore contains 'enough facts to state a claim to relief that is plausible on its face"' (quoting Twombly, 550 U.S. at 570)). It is also significant that Twombly makes a point of noting that allegations of parallel conduct might be sufficient when the background circumstances make the conduct harder to explain in competitive terms. See Twombly, 550 U.S. at 556 n.4. In $I q b a l$, the allegations hardly describe proper law enforcement behavior and as the court of appeals in Iqbal v. Hasty recognized, the background circumstances are not neutral with respect to Ashcroft's and Mueller's involvement. See Iqbal, 490 F.3d at 165-66.

137 Two additional points deserve special mention. First, although I believe the best interpretation is to associate Iqbal with a thick screening model, it is also possible that the Court applies a thin screening model with a high confidence threshold. This interpretation would be consistent with a focus on the likelihood of trial success if trial success were used as a measure of confidence-as in the stronger the case appears, the greater the confidence that it is not meritless. Nothing much turns on this distinction, however, because a thin screening model with a high confidence threshold, although different in theory, operates like a thick screening model in practice. Moreover, on either interpretation of Iqbal, the core difference is the same. In Iqbal, the Court dismissed based on the weakness of the case, while in Twombly, the Court dismissed based on the facial implausibility of the complaint.

Second, the Iqbal Court's discussion of the substantive standard for supervisory liability confuses matters a bit. The Court holds that Ashcroft and Mueller are not liable unless they themselves had a discriminatory purpose. See Iqbal, $129 \mathrm{~S}$. Ct. at 1949. Plaintiffs will usually prove discriminatory purpose circumstantially, of course, but the Court does not offer much insight into what constitutes an adequate circumstantial case against Ashcroft and Mueller. This can affect evaluation of the complaint at the pleading stage. The stronger the circumstantial case that is required, the more might be demanded from a complaint. However, the Court mentions that evidence showing that the defendants "condoned" the discriminatory practices of their subordinates might be enough to support an inference of discriminatory intent. See id. at 1952. Furthermore, as the court of appeals observed in Iqbal $v$. Hasty, the complaint's allegations coupled with the background circumstances suggests at least that much. See Iqbal, $490 \mathrm{~F} .3 \mathrm{~d}$ at 175 . In any event, a thin screening model with a low confidence threshold is not consistent with fine parsing of the complaint. That is the sort of thing one would expect from a court implementing a thick screening model.

138 I discuss these problems in my previous work. See Bone, supra note 7, at 926-28, 932-33. I summarize the highlights in the text and apply the analysis to the Iqbal case. 
private information, the plaintiff will not get past the pleading stage if she cannot ferret out enough facts before filing to get over the merits threshold for each element of her claim. As a result, strict pleading will screen some meritorious suits, even ones with a high probability of trial success but a probability that is not evident at the pleading stage before access to discovery.

These problems are likely to be especially serious for civil rights cases, and particularly cases like Iqbal involving state-of-mind elements. ${ }^{139}$ Because of the difficulty in obtaining specific information about mental states, many cases that would have a good chance of winning with evidence uncovered in discovery will be dismissed under a thick screening model that demands specific factual allegations at the pleading stage. Moreover, screening deserving civil rights cases is particularly troubling from a social point of view. If constitutional rights protect important moral interests, then the harm from failing to vindicate a valid constitutional claim must be measured in moral terms too. ${ }^{140}$ This means that the cost side of the policy balance includes moral harms, and moral harms must be accorded great weight. ${ }^{141}$

139 We actually know very little about the effects of Iqbal and Twombly on dismissal rates in civil rights and other types of litigation. One empirical study based on published opinions found an increase in dismissal rates after Twombly, and again after Iqbal, with the strongest impact observed in constitutional civil rights suits. Patricia W. Hatamyar, The Tao of Pleading: Do Twombly and Iqbal Matter Empirically?, 59 AM. U. L. Rev. 553, 556 (2010). By contrast, a preliminary study of district court docket entries conducted by the Administrative Office of the United States Courts revealed little effect on dismissal rates. See Admin. Office of the U.S. Courts, Motions to Dismiss: InFormation on Collection of DatA, available at http://www.uscourts.gov/rules/ Motions\%20to\%20Dismiss.pdf. These two studies provide useful information, but they also suffer from methodological limitations that are likely to skew their results. The Federal Judicial Center is currently conducting a more systematic and reliable empirical study, and we should know more about the effects of Twombly and Iqbal after that study is completed.

140 Cf. Gomez v. Toledo, 446 U.S. 635, 638-39 (1980) (noting that Section 1983 "reflects a congressional judgment that a 'damages remedy against the offending party is a vital component of any scheme for vindicating cherished constitutional guarantees'" and that the statute was "enacted to aid in the 'preservation of human liberty and human rights'" (quoting Owen v. City of Independence, 445 U.S. 622, 636, $651(1980)))$.

141 This is a rough way to summarize the analysis. More precisely, a strict pleading system should be evaluated for its impact on error costs and process costs. See Bone, supra note 7, at 910-15 (providing a more complete and rigorous account of the policy analysis). Error costs include the cost of false positives (undesirable suits that get past the pleading stage) and the cost of false negatives (desirable suits that are screened at the pleading stage by a strict pleading rule). Process costs include the cost of administering the rule, including the cost of litigating and deciding motions to 
Perhaps a stricter standard is justified in Iqbal because the defendants assert qualified immunity. Qualified immunity aims to protect government officials from litigation burdens and distractions that can interfere with effective government service. ${ }^{142}$ As long an official does not violate a clearly established constitutional right of which he should reasonably have been aware, he cannot be held liable for damages even if the court ultimately finds a constitutional violation. ${ }^{143}$ The good government policies supporting qualified immunity make the expected benefits of case screening substantially greater than in ordinary cases, and one could argue that these benefits justify the high moral costs of screening civil rights suits, at least in some cases. Moreover, because it focuses on shielding officials from unjustified litigation burdens, qualified immunity is conceived as immunity from suit, not just from liability. ${ }^{144}$ This arguably makes early screening especially important.

With social costs and social benefits substantial in qualified immunity cases, the best one can say, without more empirical information,

dismiss. To simplify the analysis, let us put process costs aside and focus exclusively on error costs. Two factors influence the magnitude of expected error costs: the probability of error and the cost of error. The social benefit of strict pleading is that it reduces the probability of false positive error. The magnitude of that benefit depends on how much the probability is reduced and the cost of the false positive errors avoided. Similarly, the social cost of strict pleading is that it increases the probability of false negative error by screening desirable suits. The magnitude of that cost depends on how much the probability is increased and the cost of the new false negative errors created. Using this framework, the point made in the text can be stated in the following way. A thick screening model is particularly problematic for civil rights suits like Iqbal because the expected cost of a strict pleading rule is likely to be very high in these cases. And it is likely to be high because the probability of a false negative is high (due to the difficulty of alleging state-of-mind elements with specificity) and the cost of a false negative is high (because that cost involves a failure to vindicate morally valuable constitutional rights). A reader might object to my characterizing the analysis as a cost-benefit balance when moral harms are involved. But doing so is useful heuristically, as long as one bears in mind that serious moral harms are not easily outweighed by ordinary cost savings on the benefit side. See id. at 912-14 (explaining "rights-based balancing").

142 See Iqbal, $129 \mathrm{~S}$. Ct. at 1953. More specifically, the doctrine recognizes that officials who are distracted by the burdens of litigation have less time to devote to government service, and that officials who are concerned about the burden of future litigation and the risk of personal liability might shy away from perfectly lawful action for fear that it might precipitate unfounded litigation. See id.

143 See Pearson v. Callahan, 129 S. Ct. 808, 816 (2009) ("Qualified immunity is applicable unless the official's conduct violated a clearly established constitutional right of which a reasonable person would have known.").

144 See, e.g., Hunter v. Bryant, 502 U.S. 224, 227 (1991); Mitchell v. Forsyth, 472 U.S. 511, 526-27 (1985). 
is that the policy case for strict pleading in suits like Iqbal is uncertain. But the Iqbal Court does not confine its holding to qualified immunity cases. It presents its two-pronged approach as the proper analysis for all cases subject to Rule $8(a)$, even those where the benefits of early screening are much weaker. ${ }^{145}$

Moreover, even in Iqbal, strict pleading might not have been the best way to achieve an optimal policy balance. The lower courts offered a promising alternative: thin screening followed by limited access to discovery before subjecting the case to a more aggressive screening approach. ${ }^{46}$ This plan allows a plaintiff to get past the pleading stage and gain access to limited discovery on the strength of a complaint that shows more than a mere possibility of discriminatory intent (although not a strong likelihood of trial success). At the same time, the defendants do not have to face broad discovery and can use summary judgment to exit the litigation if the early returns fail to provide additional support for the claim.

The Iqbal majority rejects this plan and forces the plaintiff to meet a strict pleading standard before discovery. ${ }^{147}$ It relies on Twombly's skepticism about the ability of trial judges to check discovery abuse through case management. ${ }^{148}$ To be sure, there are serious problems relying on case management to control costs and discourage frivolous suits, especially for complex antitrust class actions like Twombly. ${ }^{149}$ Those problems might also be serious in Iqbal given the magnitude and extent of post-9/11 events, but the qualified immunity and supervisory liability issues are reasonably well-defined and the lower courts' limited and staged discovery plan seems sensible. ${ }^{150}$

145 See Iqbal, 129 S. Ct. at 1949-50. The Court insists that its analysis is just what Twombly requires, and as the Court also tells us, Twombly's analysis applies to all cases subject to Rule 8. Id. at 1953.

146 See supra notes 27,33 , and accompanying text. This is similar to the proposal I develop in my Twombly article, which recommends limited access to before-screening discovery. See Bone, supra note 7, at 932-35.

147 In fact, while the appeals were pending, the plaintiff in Iqbal had access to discovery against other defendants, which might have revealed information helpful in fleshing out the allegations against Ashcroft and Mueller. This strategy, however, depends on the plaintiff suing multiple defendants and the claims against some of the defendants surviving dismissal. Many lawsuits do not fit this profile.

148 See Iqbal, 129 S. Ct. at 1953 (citing Bell Atl. Corp. v. Twombly, 550 U.S. 544, 559 (2007)).

149 See Bone, supra note 7, at 898-900; Robert G. Bone, Who Decides? A Critical Look at Procedural Discretion, 28 CARdozo L. REv. 1961, 2016-23 (2007).

150 However, the judge must be willing to grant summary judgment based on the results of substantially truncated discovery and resist the temptation to allow plaintiffs more discovery in the hope that something might eventually be uncovered. 
Given this, defendants should at least have the burden to explain why the plan is not likely to work. ${ }^{151}$

Perhaps the Court adopted a strict pleading approach because of the special circumstances of the case. Ashcroft and Mueller were high-level government officials and arguably needed maximum flexibility to formulate swift and effective responses to unexpected dangers like $9 / 11$. It would be a serious problem if the costs and risks of litigation chilled officials at this level from acting decisively. Moreover, the case deals with the chaotic aftermath of the 9/11 terrorist attacks, and there might be some reason to hesitate before unleashing broad discovery in this type of situation. Of course, one can also argue that officials have strong incentives to ignore legal constraints in emergency situations and therefore legal accountability is especially important in these circumstances. Nevertheless, insofar as these factors played a major role in the Court's decision, they favor a narrow interpretation of Iqbal that reserves its strict approach to similar situations. ${ }^{152}$

The lesson to draw from the previous analysis is that the case for strict pleading based on a thick screening model is highly problematic. There might be certain types of cases in which it is justified, including perhaps some cases involving qualified immunity, but even in those cases, limited discovery should be allowed beforehand.

By contrast, there is much to commend a thin screening model, at least one, like the Twombly Court's version, that employs a low confidence threshold. This approach screens only those cases where the complaint fails to tell an unusual enough story relative to the baseline of normality to suggest wrongdoing. Without demanding at least this much from a complaint, cases can proceed even though there is no particular reason to believe that the defendant did anything wrong, and the threat of high discovery costs can pressure even innocent defendants to settle. Moreover, allowing cases to proceed under these conditions empowers private plaintiffs to use civil adjudication primarily as an instrument of investigation. To be sure, investigation

151 See Iqbal, 129 S. Ct. at 1961-62 (Breyer, J., dissenting).

152 It is worth mentioning that, if these concerns get weight, there is a countervailing concern that perhaps should get some weight as well. The Iqbal case provides an opportunity for the public to learn about serious abuses in the wake of $9 / 11$ and to hold government officials accountable. It is possible that transparency and accountability can be achieved in other ways, such as through a government investigation, but if the alternatives are limited, then civil adjudication could be the most promising means to accomplish the result. Of course, one would still demand a viable case, but the additional value of the case as an instrument to investigate and hold officials accountable might justify a more lenient approach at the pleading stage. 
through discovery can reveal useful information, but investigation is not in itself the purpose of adjudication. That purpose is to furnish remedies for substantive law violations. Given this, it might be reasonable to demand that the complaint at least suggest legal wrongdoing before a plaintiff can use discovery to investigate extensively.

Furthermore, I have argued elsewhere that a thin approach like the one the Twombly Court uses might even be required by a general principle of faimess as reason-giving. ${ }^{153}$ This principle imposes a duty on government to give reasons before imposing significant burdens on individuals. Here the government imposes burdens by forcing defendants to answer a complaint and litigate at the risk of suffering a default judgment, and it fulfills its duty to give reasons by requiring that the plaintiff's complaint suggest legal wrongdoing. To be sure, a thin screening model will screen some meritorious suits, especially under conditions of asymmetric information. But with a low confidence threshold, the risk is likely to be much less than in a thick screening model. ${ }^{154}$

\section{Some Thoughts on How to Proceed From Here}

This analysis is complex and its complexity supports one firm conclusion. The Supreme Court is not the optimal institution to design a strict pleading rule, especially one that implements a thick screening model. ${ }^{155}$ The cost-benefit balance depends on empirical information about the frequency of meritless litigation, the difficulty of access to pre-filing information, the impact of litigation costs on government actors, and other factors. The Court is not in a good

153 See Bone, supra note 7, at 900-09.

154 Depending on the nature of the fairness objection, one might be able to reduce the risk of screening meritorious suits even further by giving the plaintiff access to very limited prescreening discovery for some types of cases, such as those where information-access obstacles are extremely high-at least as long as the discovery is not so burdensome as to trigger serious fairness concerns.

155 See Bone, supra note 7, 930-36; see also Burbank, supra note 134, at 559 ("The Twombly Court ... was not well positioned institutionally to evaluate even the procedural costs and benefits of tightening the pleading screws on plaintiffs, even in the isolated substantive-law context involved in the case."). Ironically, the Supreme Court has repeatedly made this point itself, holding that federal courts have no common law power to make heightened pleading rules on their own and that this must be done through the formal rulemaking process or by Congress. See Bell Atl. Corp. v. Twombly, 550 U.S. 544, 569 n.14 (2007); Swierkiewicz v. Sorema N.A., 534 U.S. 506, 515 (2002); Leatherman v. Tarrant County Narcotics Intelligence \& Coordination Unit, 507 U.S. 163, 168 (1993). If I am correct that the Iqbal Court applies a thick screening model, then the Court ignores these earlier holdings without admitting that it is doing so. 
position to gather and process this information. Nor is the Court wellsuited institutionally to compare strict pleading to other methods for discouraging frivolous filings, such as penalties and fee shifting.

These concerns counsel in favor of giving the task of rule design to the formal rulemaking process ${ }^{156}$ or perhaps to Congress. The two bills currently pending in Congress, however, are far from optimal. ${ }^{157}$ Both bills are knee-jerk and rather crude responses to Twombly and Iqbal. Both would reinstate liberal notice pleading without taking account of the legitimate screening concerns addressed by Twombly and the strong policies favoring a thin screening model with a low confidence threshold. Moreover, both bills ignore the serious possibility that thick screening might be desirable in some cases as long as the merits threshold is not set too high and limited discovery is allowed before screening takes place.

I prefer the formal rulemaking process to Congress, and fortunately each of the two pending bills contains language that allows amendments adopted through that process to supersede the bill's provisions. ${ }^{158}$ Formal rulemaking has a number of important advantages as a way to address pleading issues. ${ }^{159}$ The rulemaking committees are more insulated from political pressure and more strongly concerned with the integrity of the procedural system as a whole, and their membership has experience with and expertise in federal civil procedure. In particular, the Advisory Committee on Civil Rules can collect and process information, assess global effects, and compare different screening options. Moreover, the Committee invites public participation by holding hearings and soliciting written input. This is especially important for proposals that restrict court access in civil rights cases given the political controversy those proposals are likely to

156 The Rules Enabling Act, 28 U.S.C. $\$ \S 2072-2073$ (2006), vests the authority to make procedural rules in the United States Supreme Court and creates a multistage rulemaking process with opportunities for public input. A proposed amendment is first considered by the Advisory Committee on Civil Rules and then works its way up the rulemaking pyramid.

157 For these two bills, see supra rotes $5 \& 6$ and accompanying text.

158 See H.R. 4115, 111 th Cong., \& 2 (2009) (“The provisions ... govern according to their terms except as otherwise expressly provided . . . by amendments made after the date of enactment of this section to the Federal Rules of Civil Procedure ...."); S. 1504, 111th Cong., $\$ 2$ (prefacing the bill text with: "Except as otherwise provided ... by an amendment to the Federal Rules of Civil Procedure which takes effect after the date of enactment of this Act").

159 For an account of the relative advantages of the formal rulemaking process, see Robert G. Bone, The Process of Making Process: Court Rulemaking, Democratic Legitimacy, and Procedural Efficacy, 87 GEO. L. J. 887, 920-26 (1999). 
generate. Perhaps then Iqbal's most serious mistake is to take on a task better left to other institutions.

\section{CONCI.USION}

Iqbal changes the pleading landscape. It adopts a two-pronged approach with a first prong that makes little sense. It purports to apply Twombly's plausibility standard in a routine manner, but actually adopts a stricter approach. It rejects sensible lower court efforts to balance competing policies and protect constitutional rights, but offers no convincing justification for the rejection. It relies on qualified immunity and extraordinary events, but does not limit its holding to cases with those features. In short, Iqbal is a major decision with an ill-advised holding and a poorly reasoned opinion.

But the problems run deeper. Iqbal illustrates the consequences of leaving strict pleading to the Supreme Court to develop case-bycase. The Court is simply not the right institution to be making these decisions. Fortunately, the Advisory Committee on Civil Rules and the Standing Committee are currently giving serious attention to Twombly and Iqbal. These committees are taking a careful and measured approach, collecting empirical information and studying the issues before entertaining reform proposals. We can only hope that the result will be a sensible set of pleading rules based on strong empirics and a rigorous policy analysis and striking a sound balance among the competing values at stake in regulating court access. 
